East African Journal of Science, Technology and Innovation, Vol. 1 (1): 2019, 11-26.

This article is licensed under a Creative Commons license, Attribution 4.0 International (CC BY 4.0)

\title{
Factors associated with leg cleanliness of smallholder dairy herds in Kenya
}

\author{
1,2*KIMELI P., 1MAKAU D, 1 VAN LEEUWEN J., 2 GITAU G., 1,2 MURAYA J., ${ }^{1}$ MCKENNA \\ S., 1 HEIDER L \\ ${ }^{1}$ Department of Health Management, Atlantic Veterinary College, Charlottetown, PEI \\ ${ }^{2}$ Department of Clinical Studies, Faculty of Veterinary Medicine, Nairobi, Kenya \\ *Corresponding author: kimeli08@yahoo.com
}

\begin{abstract}
Dairy cow cleanliness provides information about animal welfare, along with risk of diseases and quality of housing environments. This study determined animal- and farm-level factors associated with upper hind leg cleanliness in smallholder dairy cows. All lactating cows $(n=234)$ on 118 randomly selected zero-grazing fams participated in this cross-sectional study between May to August 2015 in the Naari area of Meru County, Kenya. Cleanliness scores of hind legs were assessed visually on a 1-4 ordinal scale (clean to very soiled). Potential risk factors for poor leg cleanliness were evaluated by inspection of cows and their housing, along with a questionnaire about herd management. Descriptive statistics, and univariable and multivariable logistic regression were used to determine factors associated with soiled legs (cleanliness score $>2$ ) in the analyses. Prevalence of soiled legs was $59.0 \%$ $(137 / 234)$. In the final model, factors positively associated with soiled legs included failure of the knee wetness test on the stall floor $(\mathrm{OR}=11.2$; $95 \% \mathrm{CI}$ : 5.1, 24.7), animal restlessness in the stall $(\mathrm{OR}=4.9$; $95 \% \mathrm{CI}: 1.8,13.5)$, and milk production in $\mathrm{kg} / \mathrm{cow} /$ day (OR=1.09; $95 \% \mathrm{CI}: 1.02,1.16)$. Protective factors for soiled legs included having stalls without excessive space (OR=0.25; 95\%CI: $0.11,0.57)$, and having an intact stall roof $(\mathrm{OR}=0.34 ; 95 \% \mathrm{CI} ; 0.15,0.76)$. Our results suggest that farmers should address both housing design (especially the roof and stall size) and management issues (especially stall cleanliness) to enhance leg cleanliness and animal welfare.
\end{abstract}

Keywords: welfare; cleanliness; soiled; zero-grazing; risk factors

Cite as: Peter Kimeli, 2019 Factors associated with leg cleanliness of smallholder dairy herds in Kenya. East African Journal of Science, Technology and Innovation 1(1): 11-26.

$\begin{array}{ll}\text { Received: } & 19 / 06 / 19 \\ \text { Accepted: } & 03 / 09 / 19 \\ \text { Published: } & 25 / 10 / 19\end{array}$

\section{Introduction}

Dairy cow body cleanliness has been used as an indicator of animal welfare, as it provides information about the farm facilities and the quality of life of the cows (Hultgren and Bergsten, 2001). Optimal body cleanliness in dairy herds is essential to ensure hygienic milk production, reduced cold stress and decreased risk of diseases (Hauge et al., 2012; Ruud et al., 2010). The amounts of soiling can predispose cows to skin irritation, gastro-intestinal diseases, and lameness through digital dermatitis, interdigital dermatitis, and slurry heal (Nafstad, 1999). Body soiling can also obscure skin damage and foot lesions, preventing their early detection and treatment, and thus increasing recovery times and losses. Several studies have identified relationships between cow cleanliness and measures of milk quality (Reneau, et al., 2005; Schreiner and Ruegg, 2003). These studies highlight the importance of maintaining cleanliness of areas that can come in contact with the udder. Numerous environmental and contagious mastitis pathogens have been recovered from milk samples obtained from soiled cows (Reneau, et al., 2005; Kyalo, 2009). Moisture, mud, and manure are common sources of pathogens causing mastitis and hence exposure to manure in housing areas and poor hygiene in cows can influence the rate of 
clinical mastitis (Rajabi, et al., 2017). It is therefore evident that a successful control of mastitis requires optimal cleanliness of farm environment and consequently the animal body surface.

Animal body cleanliness on the farm is affected by a range of factors (Davies et al., 2000) that include: physical and environmental conditions; management; feeding; and health and production (Lombard et al., 2010). Body soiling on cows may be caused by feces, mud, dust, and vegetative matter (Kivling, 2012). Previous studies have shown that, the primary cause of soiling of cattle is loose feces which can be caused by infections or feeding rations with excess concentrate and insufficient fiber content (Hauge et al., 2012). Additionally, a leaking roof of the stall, infrequent slurry removal, and failure to use sufficient bedding material can worsen a cow's cleanliness status (Lombard et al., 2010). It is also reported that water leakage (e.g. from drinking troughs) into lying areas increases the likelihood of detecting soiled animals in the herd (Hauge et al., 2012).

Three approaches of scoring cleanliness in dairy cows has been described by Cook (2007), and they include udder cleanliness, upper leg and flank cleanliness, and lower leg cleanliness. The upper leg approach was the focus of this study in Kenya because it represents animal welfare and cleanliness concerns relating to cows lying and/or walking in slurry.

Although there has been an effort to investigate the consequences of poor cleanliness in cow herds, few studies have focused on identifying factors associated with soiled cows. Furthermore, studies on cattle cleanliness risk factors are typically from intensive production systems in developed countries, while only a few studies (Aleri et al., 2012) are from smallholder zero-grazing farms which is the mainstay of the dairy industry in developing countries such as Kenya. Therefore, this study was designed to identify factors associated with cattle upper leg cleanliness in smallholder dairy cows reared under zero-grazing systems.

\section{Methodology}

\section{Study design, area and sampling}

A cross-sectional study was carried out on smallholder dairy farms in Naari sub-location, Meru County, Kenya, which is located at $0^{\circ} 6^{\prime} 0^{\prime \prime}$
$\mathrm{N}$ and $37^{\circ} 34^{\prime} 60^{\prime \prime}$ E. Meru County is located on the eastern slopes of Mount Kenya and is about 270 kilometers north of Nairobi, the capital city of Kenya. Naari sub-location is located in the high agricultural potential region within an altitude of approximately $2,000 \mathrm{~m}$ above sea level, and the main economic activity is livestock and crop agriculture.

A subset of data was used from a larger research project that investigated the welfare of smallholder dairy cows. The farms included in the study were from Naari Dairy Farmers Cooperative Society, a dairy group with an active membership of about 500 farmers who regularly sold milk to the collection centre. An initial sample of 200 farms was randomly selected from the registry of active members between January and May 2015 using softwarebased random number generation. From the 200 farms, farm-level inclusion criteria for the current study were: 1) housing in a zerograzing unit with a roofed stall so that stall factors of leg cleanliness could be assessed; and 2) $\leq 4$ milking cows per farm to ensure that the farms were representative of typical smallholder farms in the area. All lactating cows on the farms meeting the farm-level inclusion criteria were eligible for the study. A total of 234 animals from 118 smallholder farms were eligible for analysis in this study.

\section{Data collection}

Farmers consenting to participate in the study were visited in May-August 2015, and they answered a semi-structured questionnaire covering various cow- and farm-level factors. Cow-level information collected included: cow identification, age in years, and weight, as measured in kilograms using a dairy cow heart girth tape. The height was measured using a height stick with a level that was placed at the withers. Breeds were described as exotic (Bos taurus) if the cows were visibly and predominantly Friesian, Guernsey, Ayrshire or Jersey, and indigenous (Bos indicus) if they were visibly and predominantly Zebu, Boran or Sahiwal. Cows were scored visually for body condition on a five-point scale in increments of 0.5 , with 1 being thin and 5 being fat (Edmonson et al., 1989). Leg cleanliness scores were assessed using a 4-point scoring system of the two hind legs (Cook 2004) where the categories included: 1 (no soiling), 2 (minor 
splashing of soiling), 3 (distinct plaques of soiling) and 4 (confluent plaque of soiling). The scores from the 2 hind legs were averaged and recorded. Assessments for abnormal lying and standing behaviors were captured for each cow by visual monitoring while on the farm, and asking the owner about the behaviors. Such behaviors included perching, standing idly in the stall, standing backwards in the stall, and lying in places other than the stall.

The farm-level factors evaluated included: number of adults per household; age, gender, marital status and education level of the principal farmer; land size allocated to dairy farming; stall roof and floor characteristics; and slurry management. The stall where cows usually lie in was measured (length and width) and the area computed. The stall roof status was determined based on a visual assessment, confirming that the roof was adequately covering the entire length of the stall, plus an extra foot of roofing at the udder end, with a roof that was not allowing rain water to enter the stall because of roof holes. Inadequate drainage of the stall area was judged by determining if water pooled on the stall floor or if water runoff could flow along the ground from outside into the stall by gravity.

\section{Data analysis}

Data were first entered into MS Excel (Microsoft Inc., Sacramento, California, USA) and then imported to Stata 15 (StataCorp LLC, College station, Texas, USA) for analyses. Initially, the data were checked for accuracy, coded and analyzed using descriptive statistics. Proportions were determined for categorical variables, and ranges, means, standard deviations and medians were determined for continuous variables. The leg cleanliness score was transformed into a dichotomous variable where cleanliness score 1 and 2 were categorized as clean, while 3 and 4 were categorized as soiled.

Univariable analysis using simple logistic regression was performed to determine unconditional associations with the dichotomized leg cleanliness score. The predictors were chosen from the available data based on a causal diagram and biological plausibility of an association with the dichotomized outcome. Univariable associations with $p \leq 0.25$ were eligible for multivariable analysis.
Linearity of continuous predictors was assessed by making plots against the log odds of the outcome and through "best"-fitting fractional polynomial calculations. Candidate variables were also checked for collinearity by means of variance-covariance matrix of the estimators (VCE). Multicollinearity was considered to be present if VCE is over five for any pair (Dohoo et al., 2009).

Multivariable logistic regression was performed to determine factors associated with the dichotomized leg cleanliness score, while controlling for possible confounding among model variables. The final models were built using backward stepwise elimination leaving those variables which had a p-value $\leq 0.05$.

Biologically plausible pair-wise interactions between significant variables from the final models were assessed by adding their crossproduct in the model and then determining if the coefficient for the term was statistically significant at $\mathrm{p} \leq 0.05$.

The area under the curve (AUC) of the receiver operating characteristic (ROC) was used to evaluate overall model performance. Pearson goodness-of-fit test was used as a test for the model's goodness-of-fit. Residual and influential analysis was performed to assess the reliability of the model, as described by Dohoo et al. (2009).

\section{Results}

\section{Animal-and farm-level characteristics of study farms}

A summary of farm demographics is shown in Table 1(a) and 1(b). On the118 farms, each household had an average of nearly 4 adults per household. On average, farmers owned less than two acres of land, with nearly half of it dedicated to dairy animal keeping and fodder production.

The gender of the principal farmers responsible for farm operations was mainly female. Generally, both men and women farmers averaged over forty years old with a majority of them being married. Less than a quarter of the women and men involved in farming had only a primary education level. 
A total of 234 cows from 118 smallholder farms were eligible for this study. Summary of the cow characteristics are shown in Table 1(a) and 1(b).

Table 1a:

Descriptive statistics of continuous variables, and significance of associations with soiled legs for lactating cows on 118 smallholder dairy farms in Kenya in 2015

\begin{tabular}{|c|c|c|c|c|c|c|}
\hline Variable & Mean & Sd & Median & Range & Number & $\begin{array}{l}\text { p- } \\
\text { value }\end{array}$ \\
\hline \multicolumn{7}{|l|}{ Farm-level factors: } \\
\hline Number of adults per household & 3.59 & 1.60 & 3 & $1-11$ & 118 & 0.261 \\
\hline Age of women farmers & 42.64 & 17.11 & 45 & $0-85$ & 117 & 0.388 \\
\hline Age of men farmers & 42.94 & 21.24 & 47 & $0-90$ & 117 & 0.074 \\
\hline Land size (acres) & 1.93 & 1.89 & 1.5 & $0.25-13$ & 118 & 0.037 \\
\hline$\%$ of land used for dairy production & 46.56 & 20.60 & 50 & $5-95$ & 117 & 0.680 \\
\hline Average stall area $\left(\mathrm{m}^{2}\right)$ & 2.02 & 0.56 & 1.98 & $0.02-4.37$ & 112 & 0.910 \\
\hline \multicolumn{7}{|l|}{ Animal-level factors } \\
\hline Age (yr) & 5.92 & 2.44 & 6 & $2-17$ & 214 & 0.311 \\
\hline Weight (kg) & 390.33 & 71.44 & 389 & 179-695 & 234 & 0.666 \\
\hline Height $(\mathrm{cm})$ & 118.48 & 11.20 & 119 & $115-190$ & 234 & 0.538 \\
\hline Body condition score (scale 1-5) & 2.16 & 0.63 & 2 & $1-4$ & 234 & 0.036 \\
\hline Current daily milk yield (kg) & 6.63 & 4.96 & 6 & $0-27$ & 232 & 0.017 \\
\hline $\begin{array}{l}\text { Cases of clinical mastitis in the last } 12 \\
\text { months }\end{array}$ & 0.55 & 0.91 & 0 & $0-6$ & 232 & 0.256 \\
\hline
\end{tabular}


Table 1b

Descriptive statistics of categorical variables, and significance levels of differences in proportions of dirty legs by categories, for 234 cows on 118 smallholder dairy farms in Kenya in 2015

\begin{tabular}{|c|c|c|c|c|}
\hline Variable & Category & $\begin{array}{l}\text { Number } \\
(\%)\end{array}$ & $\begin{array}{l}\text { Proportion } \\
\text { with soiled } \\
\text { legs }(\%)\end{array}$ & p-value \\
\hline \multicolumn{5}{|l|}{ Farm-level factor $(n=118)$} \\
\hline \multirow{3}{*}{$\begin{array}{l}\text { Gender of principal } \\
\text { farmer(s) }\end{array}$} & Female & $62(52.5)$ & $40(64.5)$ & $0.838^{\mathrm{a}}$ \\
\hline & Male & $35(29.7)$ & $23(65.7)$ & \\
\hline & Both male and female & $21(17.8)$ & $13(61.9)$ & \\
\hline \multirow{3}{*}{$\begin{array}{l}\text { Marital status of the } \\
\text { principal farmer }\end{array}$} & Single & $13(11.0)$ & $8(61.5)$ & $0.062^{a}$ \\
\hline & Married & $95(80.5)$ & $59(62.1)$ & \\
\hline & widowed & $10(8.5)$ & $9(90.0)$ & \\
\hline \multirow[t]{3}{*}{ Men's education } & Primary & $18(16.8)$ & $13(72.2)$ & $0.131^{a}$ \\
\hline & Secondary & $43(40.2)$ & $30(69.8)$ & \\
\hline & College/University & $46(43.0)$ & $28(60.9)$ & \\
\hline \multirow[t]{3}{*}{ Women's education } & Primary & $13(12.3)$ & $8(61.5)$ & $0.572^{\mathrm{a}}$ \\
\hline & Secondary & $52(49.1)$ & $37(71.2)$ & \\
\hline & College/University & $41(38.7)$ & $24(58.5)$ & \\
\hline \multirow[t]{2}{*}{ Floor type } & Concrete & $7 \quad(6.1)$ & $5(71.4)$ & 0.611 \\
\hline & Earthen & $107(93.9)$ & $68(63.6)$ & \\
\hline \multirow[t]{2}{*}{ Uneven floor } & Present & $71(60.2)$ & $45(63.4)$ & 0.917 \\
\hline & Absent & $47(39.8)$ & $31(66.0)$ & \\
\hline \multirow[t]{6}{*}{ Type of bedding used } & Grass & $2(1.7)$ & $2(100.0)$ & $0.013^{a}$ \\
\hline & Straw & $7(5.9)$ & $6(85.7)$ & \\
\hline & Sawdust & $45(38.1)$ & $24(53.3)$ & \\
\hline & Crop residue & $20(17.0)$ & $16(80.0)$ & \\
\hline & Soil & $2(1.7)$ & $1(50.5)$ & \\
\hline & None & $42(35.6)$ & $27(64.3)$ & \\
\hline \multirow{3}{*}{$\begin{array}{l}\text { Frequency of adding new } \\
\text { bedding to the stall }\end{array}$} & Everyday & $4 \quad(4.7)$ & $2(50.0)$ & $0.211^{\mathrm{a}}$ \\
\hline & 1-3 times a week & $25(29.1)$ & $17(68.0)$ & \\
\hline & Once a month & 57 (66.3) & $34(59.7)$ & \\
\hline \multirow[t]{2}{*}{ Failed knee impact test } & Yes & $46(39.0)$ & $32(69.6)$ & $<0.001$ \\
\hline & No & $72(61.0)$ & $44(61.1)$ & \\
\hline \multirow[t]{2}{*}{ Intact stall roof } & Yes & $84(71.2)$ & $49(58.3)$ & 0.007 \\
\hline & No & $34(28.8)$ & $27(79.4)$ & \\
\hline \multirow{2}{*}{$\begin{array}{l}\text { Lack of excess space in } \\
\text { the stall }\end{array}$} & Yes & $25(21.2)$ & $11(44.0)$ & 0.013 \\
\hline & No & 93 (78.8) & $65(69.9)$ & \\
\hline \multirow{3}{*}{$\begin{array}{l}\text { Frequency of slurry } \\
\text { removal from the stall } \\
\text { and alleyways }\end{array}$} & Every day & $70(59.3)$ & $46(65.7)$ & $0.771^{\mathrm{a}}$ \\
\hline & 1-3 times a week & $31(26.3)$ & $19(61.3)$ & \\
\hline & Once a month & $17(12.7)$ & $11(66.7)$ & \\
\hline \multirow[t]{2}{*}{ Failed knee wetness test } & Yes & $45(38.1)$ & $39(86.7)$ & $<0.001$ \\
\hline & No & 73 (61.9) & $37(50.7)$ & \\
\hline \multirow{2}{*}{$\begin{array}{l}\text { Good drainage by } \\
\text { gravity from the alley }\end{array}$} & Present & $43(36.4)$ & $33(76.7)$ & 0.065 \\
\hline & Absent & $75(63.6)$ & $43(57.3)$ & \\
\hline \multicolumn{5}{|c|}{ Animal-level factors $(n=234)$} \\
\hline \multirow{5}{*}{ Cow breed } & Friesian & $117(50.0)$ & $68(58.1)$ & $0.193^{a}$ \\
\hline & Ayrshire & $23(9.8)$ & $14(60.9)$ & \\
\hline & Guernsey & $74(31.6)$ & $49(66.2)$ & \\
\hline & Jersey & $3(1.3)$ & $1(33.3)$ & \\
\hline & Local & $17(7.3)$ & $6(35.3)$ & \\
\hline
\end{tabular}




\begin{tabular}{lllll}
\hline Parity & 1 & $65(29.6)$ & $40(61.5)$ & $0.568^{\mathrm{a}}$ \\
& 2 & $55(25.0)$ & $35(63.6)$ & \\
& 3 & $45(20.5)$ & $23(51.1)$ & \\
& 4 & $31(14.1)$ & $16(51.6)$ & \\
& $5+$ & $24(10.9)$ & $16(66.7)$ & \\
\hline Lying outside the stall & Present & $97(42.7)$ & $46(47.4)$ & 0.008 \\
& Absent & $130(57.3)$ & $85(65.4)$ & \\
\hline Restless behaviour in the & Yes & $30(13.4)$ & $23(76.7)$ & 0.023 \\
stall & No & $194(86.6)$ & $105(54.1)$ & \\
\hline Perching behaviour & Present & $94(57.5)$ & $54(57.5)$ & 0.780 \\
& Absent & $127(42.5)$ & $71(55.9)$ & \\
\hline Idle standing in the stall & Present & $55(24.2)$ & $30(54.6)$ & 0.608 \\
& Absent & $172(75.8)$ & $101(58.7)$ & \\
\hline Overgrown claws & Present & $39(16.7)$ & $24(61.5)$ & 0.703 \\
& Absent & $195(83.3)$ & $114(58.5)$ & \\
\hline
\end{tabular}

a: overall $p$-values for variables with $>2$ categories, and reference category for the overall univariable test

The cows had an average estimated age of nearly six years, body weight of about $390 \mathrm{~kg}$ and average height at the withers of about 118 $\mathrm{cm}$. The average body condition score was below average (scale1-5), with over $80 \%$ of animals scoring less than score 2.5. Cows were in various parity levels ranging from 1 to $5+$, with more than half being in parity 1 and 2 . The herds mainly comprised of Friesian, Guernsey and Ayrshire. The other minor breeds were Jersey and local breeds such as Boran, Zebu and Sahiwal. The average daily milk production was almost $7 \mathrm{~kg} /$ cow, with the highest mean production observed in cows in $3^{\text {rd }}$ parity. Clinical mastitis had occurred in about half of the cows in the last twelve months, on average.

Less than half of the cows examined in this study were reported to lie outside their stall. It was noted that nearly two-thirds of cows spent time perching in the stall rather than lying down soon after entering the stall. Some cows $(<25 \%)$ did manifest restless behaviour and idle standing in the stall. Overgrown claws were observed in some cows and this was reported to be mainly attributed to failure of claw trimming.

A summary of housing characteristics is shown in Table 1(a) and 1(b). Generally, the stalls had a earthen (dirt) base and were small with an average area of about $2 \mathrm{~m}^{2}$. A few of the stalls had a lack of excessive space, limiting the ability of the cow in the stall to stand or lie down diagonally or too far forward. Nearly two-thirds of the farms had uneven floors, with sticks, rocks and potholes making the floors undesirable for lying down. While a third of farms used no bedding, saw dust was used as bedding on one-third of the farms, while a few of the farmers used grass, straw or crop residue. Among the farmers who used bedding, more than a half added new bedding less than once a month, which may have influenced the observed moderate frequency of failure of the knee impact test. Most of the stalls had a good intact roof to prevent rain leakage. Even though more than half of the farms had daily removal of slurry from the stall and alleyways, more than a third of the farms failed the knee wetness test. It was also noted that about a third of the farms had a good gradient on the floor that allowed easy slurry drainage from the stall by gravity.

The distribution of the cleanliness scores on the 4-category scale from 1 (clean) to 4 (very soiled) varied, with 2 and 4 having the highest frequency. The overall mean leg cleanliness score was $2.8 \pm 1.0$. On a dichotomized scale, soiled legs were found on $59.0 \%$ of the cows $(137 / 234)$.

\section{Factors associated with upper leg cleanliness of dairy cows}

Results from the univariable logistic regression analyses with leg cleanliness as a binary outcome variable ( $1 / 0$ for soiled / not soiled) are presented in the Table 1(a) and 1(b). The following cow-level variables met the $p$-value $\leq 0.25$ inclusion criterion for the multivariable analyses: breed; restless behaviour in the stall; lying outside the stall; and body condition score. The following farm-level variables met 
the $p$-value $\leq 0.25$ inclusion criterion for the multivariable analyses: marital status of the principal farmer; men's education level; lack of excessive space in the stall; failed knee wetness test; stall roof appropriateness; type of bedding; Table 2:

Final multivariable logistic regression analysis results for soiled legs belonging to 234 cows on 118 smallholder dairy farms in Kenya in 2015

\begin{tabular}{lllll}
\hline Variable & OR & 95\%CI & & p-value \\
\cline { 3 - 4 } & & LCL & UCL & \\
\hline Intact stall roof & 0.34 & 0.15 & 0.76 & 0.008 \\
Lack of excess space in the stall & 0.25 & 0.11 & 0.57 & 0.001 \\
Current daily milk yield (kg) & 1.09 & 1.02 & 1.16 & 0.012 \\
Restlessness behaviour in the stall & 4.91 & 1.79 & 13.48 & 0.002 \\
Failed knee wetness test & 11.20 & 5.08 & 24.69 & $<0.001$ \\
\hline
\end{tabular}

The odds ratios of the final multivariable logistic regression model (Table 2) revealed that factors positively associated with soiled legs included failure of the knee wetness test on the stall floor, animal restlessness in the stall, and milk production. Protective factors for soiled legs included having stalls without excessive space and having an intact roof over the stall.

None of the interaction terms was significant at the five percent level and therefore they were omitted from the model. Assessment of daily milk production as a continuous variable for linearity of log odds did not show significant departure from linearity. The Pearson goodness-of-fit test was not significant $(p=0.3501)$ which suggests that the model did fit the data well. The sensitivity of the model was slightly higher at $73.8 \%$ compared with specificity which was $70.8 \%$, based on the cutpoint of 0.50 . The area under the ROC curve was 0.80 , indicating a good overall fit of the model to the observed data.The plot of residuals against the predicted values revealed four outlier observations which had little effect on the model when omitted.

\section{Discussion}

The findings of this study showed that almost half of the dairy cows in the smallholder zerograzing units had soiled (score $>2$ ) upper hind legs, which could be contributing to the high report of clinical mastitis occurrence in the last 12 months. Failure of the knee wetness test on the stall floor, animal restlessness in the stall and milk production were positively associated with high leg cleanliness scores. Conversely, frequency of adding new bedding to the stall; failed knee impact test; good drainage of slurry by gravity from alley; type of bedding used; age of the male farmer; and land size. having stalls without excessive space and having an intact stall roof were identified as protective factors for soiled legs, providing specific stall design and management characteristics for farmers to monitor for deficiencies.

The overall mean leg cleanliness score was 2.8 \pm 1.0 and this was high when compared with $2.3 \pm 0.7$ reported on the same scale by Schreiner and Ruegg (2003). The observed prevalence of soiled legs of $59.0 \%$ of cows was also high when compared with that reported by Hauge et al. (2012) and Schreiner and Ruegg (2003) who documented $37 \%$ and $30 \%$, respectively. Although, Aleri et al. (2012) reported soiled legs in all cows in a study carried out on periurban Nairobi, the cleanliness assessment was only based on presence or absence of soiling. Our current study applied a four-level ordinal scale of cleanliness scores, with animals having scores greater than two being considered soiled.

Lack of an intact roof over the cow stalls was significantly associated with soiled legs. In an earlier study, farms which had incomplete stall roofs or damaged corrugated iron sheets were susceptible to direct rainfall into the stall, especially during the wet season (Aleri et al., 2011). Rain accumulation could exacerbate cow soiling with animal feces and urine. Building an appropriate roof to protect the stall area and repairing or replacing damaged corrugated roof sheets is therefore important in achieving good stall and cow cleanliness and good cow comfort. 
Animals that produced more milk were more likely to be categorized as soiled. In another study within the same region of Kenya, Richards (2017) reported increased milk production when additional volumes of concentrates were fed to cows on smallholder farms. Ward et al. (2002) showed that the use of high concentrate diets is associated with loose feces and reduction in cow and facility cleanliness. The observed loose feces is potentially associated with metabolic conditions such ruminal acidosis. Therefore, cows with high daily milk production that receive high volumes of concentrate supplementation likely result in the production of loose feces and potentially body soiling. It is important to maintain good manure and stall management when utilizing concentrate supplementation in milking cows in order to maintain good stall and cow cleanliness.

While our study documented varied housing designs between and within farms, it was noted that lack of excess space within the animal stall was negatively associated with animals being soiled. Previous studies have shown that cows that rest in an excessively spacious stall lie diagonally which increases deposition of manure within the stall area (Cook, 2004). This fecal matter can contaminate the bedding material and is ultimately transferred directly to the limbs, ventral abdomen and udder of the cow. Additionally, the soiled tail is more likely to transfer the feces to the rear part of the animal (Cook, 2004; Tucker et al., 2004). A stall should be big enough that a cow can and will lie down in it, as opposed to in the alley if it is too small or obstructive, but not too big, otherwise the stall will not stay clean.

This study indicated a pronounced positive association between the failure of the knee wetness test and soiled legs. Not surprisingly, wet dirty stalls are likely to lead to soiled cows. This finding is consistent with that reported by Aleri et al. (2012). Slurry is formed when manure is mixed with urine and sometimes rain water from a leaking roof, and can be a challenge to remove if the stall floor is not graded sufficiently to allow drainage. Slurry accumulation has been shown to predispose cows to mastitis and lameness in Kenyan smallholder farms (Nguhiu-Mwangi et al., 2008; Aleri et al., 2012; Kimeli et al., 2015). Inconsistent slurry removal (Aleri et al., 2012) and lack of bedding in Kenyan smallholder farms have been incriminated for slurry accumulation that consequently causes poor cleanliness when cows lie on contaminated floors. An increase in udder and hind leg cleanliness scores were positively associated with increased individual cow somatic cell count (Reneau et al., 2005; Ellis et al., 2006; Wojciech et al., 2016), and increased probability of isolating pathogens from the milk (Schreiner and Ruegg, 2003). However, there was no relationship between farmer reported clinical mastitis and body soiling (Table 1a) in our study. Moisture, mud, and manure present in the environment of the cows have been shown to be the primary sources of exposure for environmental mastitis pathogens, and high cleanliness scores of cows on smallholder dairy farms (Mureithi and Njuguna, 2016).

Bedding use was only significantly associated with soiled cow legs in our univariable analyses. However, with knee wetness test in the final model, and bedding use likely being associated with stall wetness, knee wetness was likely an intervening variable between bedding use and the outcome variable.

Hughes (2001) suggested that farmers who are daily handling the same cattle frequently failed to observe that the cows were becoming more soiled, and as such, farmers became tolerant to the animals' unacceptable condition. Awareness, motivation and attitudes of the farmer are important in provision of cleanliness on the farm. We speculate that this tolerance of the cattle's condition might have been the case in our current study. It is also crucial to note that smallholder dairy farming in Kenya is run by impoverished farmers whose priority is securing basic family needs such as food, and thus, concerns for cow health and welfare tend to be superseded by other family livelihood concerns.

The study also revealed that restless behaviour in the stall was positively associated with the odds of becoming dirty. Restlessness, which is affected by lying down time, has been shown to decrease in early lactation compared with later in lactation and during heats (Steensels et al., 2012). Poor stall designs with obstructions have also been reported to affect behavioural changes (Cook and Nordlund, 2009). The attitude and behaviour of the animal handler will also affect the behaviour of the cow, and it has been shown that negative tactile handling 
increases restless behaviour in cows (Waiblinger et al., 2002).

Language barrier was a major limitation in this study. Most elderly farmers spoke in Kimeru and therefore an interpreter was always used. Questions that probed the personal life of the respondent were treated with suspicion, but the farmers were assured of confidentiality of the collected information. Data quality was considered good by the researchers because collection was carried out by a well-trained team, and the questionnaire used was adopted from a previous study, and thus it had been pretested and modified.

Since this was a cross-sectional study, we cannot use results herein to determine causality of the model factors. Given the random sampling employed in this study, the results obtained has minimal bias and may be used as a guide for future research. There is need to further investigate the impact of body cleanliness on milk yield and disease occurrence.

\section{Conclusions}

This study concludes that to safeguard one aspect of cow comfort, optimal cow cleanliness, farmers should address both housing design (stall size and intact roof) and stall floor management issues. This study highlighted the pressing need of putting more emphasis on the appropriate roof and stall size as well as maintenance of stall cleanliness and proper nutrition of the cows. The results of this study can be considered as a baseline for implementing cow comfort improvement programs in the smallholder dairy farms.

\section{Acknowledgements}

We are grateful to the primary funding program for this research, the Canadian Queen Elizabeth II Diamond Jubilee Scholarships (QES) which are managed through a unique partnership of

Universities Canada, the Rideau Hall Foundation (RHF), Community Foundations of Canada (CFC) and Canadian universities. This program is made possible with financial support from the

Government of Canada, provincial governments and the private sector. We also acknowledge the immense support from The Sir James Dunn Animal Welfare Centre (SJDAWC) and the large contribution made by volunteers and staff of Farmers Helping Farmers, a non-governmental organization their existing relationships and agricultural efforts and inputs provided a strong foundation for the work and the entry point to the Naari community. As well, the support of the Naari Dairy Cooperative Society and the cooperation of Upendo Women's Group and the primarily women dairy farmers made it all possible.

\section{Reference}

Aleri, J.W., Nguihiu-Mwangi, J., and Mogoa, E.M., (2011). Housing-design as a predisposing factor for injuries and poor welfare in cattle within smallholder units in periurban areas of Nairobi, Kenya. Livest. Res. Rural. Dev., 23,3.

Aleri, J.W., Nguihiu-Mwangi, J., Mogoa, E.M., and Mulei, C.M., (2012). Welfare of dairy cattle in the smallholder (zero-grazing) production systems in Nairobi and its environs. Livest. Res. Rural. Dev., 24,9.

Cook, N.B., (2004). The cow comfort link to milk quality. Proc Nat Mast Council Reg Meeting, Bloomington, Minnesota, pp 1930, 2004. (https://pdfs.semanticscholar.org/cd6f/a9 5cb144caf38689bc0356d3640925b62d19.pdf)

Cook, N.B., and Reinemann, D.J., (2007). A Toolbox for Assessing Cow, Udder and Teat Hygiene. Paper presented at the 2007 Annual Meeting of the National Mastitis Council.

Cook, N.B., and Nordlund, K.V. (2009). The influence of the environment on dairy cow behavior, claw health and herd lameness dynamics. Vet J. 179, 360-369. https://doi.org/10.1016/j.tvj1.2007.09.016

Davies, M.H., Webster, S.D., Hadley P.J., and Stosic, P.J., (2000). Production factors that influence the hygienic condition of finished beef cattle. Vet. Rec. 146, 179-183. http:/ /dx.doi.org/10.1136/vr.146.7.179

Dohoo, I., Martin, W., and Stryhn, H., (2009). Veterinary Epidemiologic Research. Second edition. VER inc. Charlottetown, PEI, Canada.

Edmonson, A. J., Lean, I. J., Weaver, L. D., Farver, T., and Webster, G. (1989). A body 
condition scoring chart for Holstein dairy cows. J. Dairy Sci. 72, 68-78. https://doi.org/10.3168/jds.S00220302(89)79081-0

Ellis, K.A., Mihm, M., Innocent, G., Cripps, P., Mclean, W.G., Howard, C.V., and GroveWhite, D., (2006). The effect of farming system on dairy cow cleanliness in the UK and the implications to udder health. Aspects of Applied Biology, 79.

Hauge, S.J., Kielland, C., Ringdal, G., Skjerve, E., and Nafstad, O., (2012). Factors associated with cattle cleanliness on Norwegian dairy farms. J. Dairy Sci. 95 :2485-2496.

https://doi.org/10.3168/jds.2011-4786

Hughes, J., (2001). A system for assessing cow cleanliness. In Practice, 23, 517-524. http://dx.doi.org/10.1136/inpract.23.9.517

Hultgren, J., and Bergsten, C., (2001). Effects of a rubber-slatted flooring system on cleanliness and foot health in tied dairy cows. Prev. Vet. Med. 52, 75-89. https://doi.org/10.1016/S01675877(01)00237-9

Kimeli, P., Nguhiu-Mwangi, J., Mogoa, M. E., Onono, J. O., and Serem, J. K., (2015). Effects of floor characteristics on locomotion scores in dairy cows under smallholder zerograzing units in Kikuyu District, Kenya. Global Veterinaria, 14, 6, 837-841. DOI: 10.5829/idosi.gv.2015.14.06.94225

Kivling, S., (2012). Effect of grazing and housing system on dairy cows' hygiene, claw and leg health. Master of Science thesis. Swedish University of Agriculture Sciences.

(https://stud.epsilon.slu.se/5285/1/kivlin g_s_130215.pdf)

Kyallo, V.K., (2009). Farm factors associated with milk rejection at dairy cooperatives in peri-urban Nairobi. Master of Science thesis University of Nairobi. (erepository.uonbi.ac.ke/handle/11295/22 114).

Lombard, J.E., Tucker, C.B., von Keyserlingk, M. A. G., Kopral, C. A., and Weary, D.M., (2010). Associations between cow hygiene, hock injuries, and free stall usage on US dairy farms. J. Dairy Sci. 93, 4668-4676. https://doi.org/10.3168/jds.2010-3225

Mureithi, D.K., and Njuguna, M. N., (2016). Prevalence of subclinical mastitis and associated risk factors in dairy farms in urban and peri-urban areas of Thika Sub
County, Kenya. Livest. Res. Rural. Dev., 28, 2.

Nafstad, O., (1999). Injuries and quality defects in Norwegian cattle hides. Norsk Veterinar. Tidsskrift 111, 311-319. (in Norwegian)

Nguhiu-Mwangi, J., Mbithi, P.M.F., Wabacha, J.K., and Mbuthia, P.G., (2008). Factors associated with the occurrence of claw disorders in dairy cows under smallholder production systems in urban and peri-urban areas of Nairobi, Kenya. Veterinarski Archiv 78, 4, 345-355.

Reneau, J.K., Seykora, A.J., Heins, B.J., Endres, M.I., Farnsworth, R.J., and Bey, R. F., (2005). Association between hygiene scores and somatic cell scores in dairy cattle. JAVMA. 221, 1297-1301.

Richards, S., VanLeeuwen, J., Shepelo, G., Gitau, G.K., Kamunde, C., Uehlinger, F., and Wichtel, J., (2015). Associations of farm management practices with annual milk sales on smallholder dairy farms in Kenya. Vet. World. 8, 1, 88-96. 10.14202/vetworld.2015.88-96.

Ruud, L.E., Boe, K.E., and Osteras, O., (2010). Risk factors for dirty dairy cows in Norwegian freestall systems. J. Dairy Sci. 93, 52165224. https://doi.org/10.3168/jds.2010-3321

Schreiner, D.A., and Ruegg, P.L., (2003). Relationship between udder and leg hygiene scores and subclinical mastitis. J. Dairy Sci. 86, 3460-3465. https://doi.org/10.3168/jds.S00220302(03)73950-2

Tucker, C.B., Weary, D.M., and Fraser, D., (2004). Free-stall dimensions: effects on preference and stall usage. J. Dairy Sci. 87, 1208-1216. https://doi.org/10.3168/jds.S00220302(04)73271-3

Ward, W.R., Hughes, H.W., Faull, W.B., Cripps, P.J., Sutherland, J.P., and Sutherst, J.E., (2002). Observational study of temperature, moisture, $\mathrm{pH}$ and bacteria in straw bedding, and fecal consistency, cleanliness and mastitis in cows in four dairy herds. Vet. Rec. 151, $199 \quad-206$. http://dx.doi.org/10.1136/vr.151.7.199

Wojciech, N., Mariusz, B., Małgorzata, J., and Anna, S., (2016). Effect of cow cleanliness in different housing systems on somatic cell count in milk. Acta Vet. Brno. 85, 055-061. https://doi.org/10.2754/avb201685010055

Waiblinger, S., Menke, C., and Coleman, G. (2002). The relationship between attitudes, 
personal characteristics and behaviour of stockpeople and subsequent behaviour and production of dairy cows. Appl. Anim. Behav. Sci., 79(3), pp. 195-219. https://doi.org/10.1016/S01681591(02)00155-7

Steensels, M., Ba

DOI: $10.22067 /$ veterinary.v9i1.57689 hr, C., Berckmans, D., Halachmi, I., Antler, A., and Maltz, E. (2012). Lying patterns of high producing healthy dairy cows after calving in commercial herds as affected by age, environmental conditions and production. Appl. Anim. Behav. Sci., 136(2-4), pp. 88-95. https://doi.org/10.1016/j.applanim.2011.1 $\underline{2.008}$

Rajabi, I., Razavizadeh T.A., Azizzadeh M., and Khoramian B. (2017). The investigation on the relationship between dairy cow hygiene scores and intramammary infections. IJVST 9(1).

DOI: $10.22067 /$ veterinary.v9i1.57689 
